\title{
Intraoperative floppy iris syndrome (IFIS): what complication rates can we expect?
}

\author{
Andrzej Grzybowski • Patrycja Krzyżanowska-Berkowska
}

Received: 12 September 2013 / Accepted: 18 November 2013 / Published online: 27 November 2013

(C) The Author(s) 2013. This article is published with open access at Springerlink.com

Dear Editor,

In a very interesting paper, Haridas et al. have shown that patients with intraoperative floppy iris syndrome (IFIS) receiving tamsulosin or doxazosin differ in terms of morbidity rates [1].

Among 2,785 cataract operations performed in 2,028 patients, the authors identified $52(1.9 \%)$ cases treated with tamsulosin and 109 (3.9 \%) cases in which doxazosin was administered. They compared morbidity rates between these two groups.

In our opinion, however, some aspects of this study need to be discussed. In their retrospective analysis, the authors found at least one IFIS feature in 17 out of 106 eyes $(16 \%)$ from the doxazosin group and in 25 out of 52 eyes ( $48 \%$ ) from the tamsulosin group. Alpha-1 antagonists, used in the symptomatic treatment of benign prostatic hyperplasia, may increase the surgical difficulties and risk of iris damage, corneal edema, posterior or anterior capsule rupture, and postoperative increase in intraocular pressure [2-4]. Nevertheless, analysis of data expressed as percentages can be misleading and provide false information on the prevalence of IFIS and expected intraoperative morbidity rate.

In Table 1 of their paper, Haridas et al. presented data on the size of the pupil and status of the iris in the tamsulosin and

\footnotetext{
A. Grzybowski $(\bowtie)$

Department of Ophthalmology, Poznan City Hospital, ul.

Szwajcarska 3, 61-285 Poznań, Poland

e-mail: ae.grzybowski@gmail.com
}

\author{
A. Grzybowski \\ University of Warmia and Mazury, ul.Żołnierska 14C, Olsztyn, \\ Poland \\ P. Krzyżanowska-Berkowska \\ Department of Ophthalmology, Wroclaw Medical University, ul. \\ Borowska 213, 50-556 Wroclaw, Poland
}

doxazosin groups [1]. However, the prevalence of various abnormalities (large or small pupil, iris prolapse, etc.) was expressed as a percentage of IFIS cases in a given group, i.e. per 25 and 17 eyes in tamsulosin and doxazosin group, respectively. In our opinion, however, the prevalence should be rather expressed per the whole group administered a given agent, i.e. per 52 and 106 eyes of patients treated with tamsulosin and doxazosin, respectively. Only in this way can we estimate the potential risk of intraoperative complications in patients treated with $\alpha-1$ antagonists. Furthermore, it should be noted that expressing seven cases of intraoperative complications in the tamsulosin group as $13.5 \%$ ( 7 out of 52 eyes) suggests that such morbidity can be expected in patients subjected to cataract surgeries. This is not true, as intraoperative complications documented in the tamsulosin IFIS group (iris damage -5 cases, anterior capsule rupture -1 case, corneal edema -1 case) corresponded to only $0.3 \%$ of all 2,785 operated eyes, the average rate of cataract complications in non-IFIS patients. Takmaz analyzed a group of 858 operated eyes and identified intraoperative complications in 6 eyes of patients who were treated with tamsulosin [8]. However, he emphasized the lack of significant differences in the morbidity rates of tamsulosin-treated patients with and without IFIS ( $p=$ 0.245). According to Haridas et al., patients treated with tamsulosin differed significantly from the controls in terms of the morbidity rates $(13.5 \%$, i.e. 7 out of 52 eyes vs. $3.3 \%$, i.e. 5 out of 150 eyes; $p=0.014$ ) [1]. However, we postulate that statistical analyses are not justified in the case of such a large disproportion in group size. Furthermore, this analysis was not adjusted for surgeon's experience and other intraoperative factors.

The exact data on the type and prevalence of intraoperative complications is missing in available literature. (Table 1) Chang et al. spoke to the intraoperative use of retractors in five cases but did not provide any data on the percentage of postoperative iris damage in patients with IFIS [2]. In turn, the 
Table 1 Studies reporting the rate of intraoperative floppy iris syndrome (IFIS) complications

\begin{tabular}{|c|c|c|c|c|}
\hline & $\begin{array}{l}\text { IFIS cases/all } \\
\text { cases }\end{array}$ & $\begin{array}{l}\text { IFIS cases } / \alpha-1 \\
\text { antagonist group }\end{array}$ & $\begin{array}{l}\text { Tamsulosin IFIS/ } \\
\text { Tamsulosin group }\end{array}$ & Complication rate ( $\%$ of all cases) \\
\hline Haridas et al [1]. (2013) & $\begin{array}{l}1,5 \% \\
42 / 2,785 \text { eyes }\end{array}$ & $\begin{array}{l}26,6 \% \\
42 / 158\end{array}$ & $\begin{array}{l}48 \% \\
25 / 52 \text { eyes }\end{array}$ & $\begin{array}{l}\text { AC rupture - } 1 \text { case }(0,04 \%) ; 5 \text { eyes } \\
\text { with iris damage }(0,2 \%) ; 1 \text { eye } \\
\text { corneal oedema }\end{array}$ \\
\hline Chang et al [2]. (2005) & $\begin{array}{l}\text { Clinical Study } 1 \\
2 \% \\
10 / 511 \text { patients }\end{array}$ & $\begin{array}{l}37 \% \\
10 / 27 \text { patients }\end{array}$ & $\begin{array}{l}63 \% \\
10 / 16 \text { patients }\end{array}$ & $\begin{array}{l}\text { PC rupture \& vitreous loss- } 2 \\
\quad \text { cases }(0,4 \%)\end{array}$ \\
\hline Chang et al [2]. (2005) & $\begin{array}{l}\text { Clinical Study } 2 \\
2,2 \% \\
16 / 741 \text { patients }\end{array}$ & $\begin{array}{l}94 \% \\
15 / 16 \text { patients }\end{array}$ & $\begin{array}{l}100 \% \\
15 / 15 \text { patients }\end{array}$ & AC rupture - 1 case $(0,1 \%)$ \\
\hline Cheung et al [5]. (2006) & $\begin{array}{l}1 \% \\
17 / 1689 \text { eyes }\end{array}$ & $\begin{array}{l}29 / 8 \% \\
17 / 57 \text { eyes }\end{array}$ & $\begin{array}{l}80 \% \\
8 / 10 \text { eyes }\end{array}$ & No complications \\
\hline Oshika et al [6]. (2007) & $\begin{array}{l}1,1 \% \\
29 / 2,643 \text { eyes }\end{array}$ & $\begin{array}{l}36,7 \% \\
29 / 79 \text { eyes }\end{array}$ & $\begin{array}{l}43,1 \% \\
25 / 58 \text { eyes }\end{array}$ & No data \\
\hline Blouin et al [7]. (2007) & $\begin{array}{l}4 \% \\
61 / 1268 \text { eyes }\end{array}$ & $\begin{array}{l}66,3 \% \\
61 / 92 \text { eyes }\end{array}$ & $\begin{array}{l}64,5 \% \\
51 / 79 \text { eyes }\end{array}$ & $\begin{array}{l}\text { PC rupture - } 1 \text { case } \\
(0,08 \%) ; 3 \text { eyes with iris damage; } \\
\text { zonular dehiscence- } 1 \text { case; retained } \\
\text { lens fragments - } 1 \text { case; CME - } \\
2 \text { cases }\end{array}$ \\
\hline Takmaz [8] (2007) & $\begin{array}{l}1,6 \% \\
14 / 858 \text { eyes }\end{array}$ & $\begin{array}{l}\text { Only patients taking } \\
\text { Tamsulosin }\end{array}$ & $\begin{array}{l}77,8 \% \\
14 / 18 \text { eyes }\end{array}$ & $\begin{array}{l}\text { PC rupture - } 1 \text { case }(0,1 \%) ; 5 \text { eyes } \\
\text { with iris damage }(0,6 \%)\end{array}$ \\
\hline Nguyen et al [9]. (2007) & Unknown & Unknown/606 cases & Unknown/363 cases & $\begin{array}{l}\text { Difficult to assess, PC rupture }-7 \% \text { of } \\
\text { unknown number of cases }\end{array}$ \\
\hline $\begin{array}{l}\text { Altan-Yaycioglu et al [10]. } \\
\text { (2009) }\end{array}$ & $\begin{array}{l}2,8 \% \\
14 / 500 \text { patients }\end{array}$ & $\begin{array}{l}66,7 \% \\
14 / 21 \text { patients }\end{array}$ & $\begin{array}{l}66,7 \% \\
6 / 9 \text { patients }\end{array}$ & $\begin{array}{l}\text { PC rupture - } 1 \text { case } \\
(0,2 \%)\end{array}$ \\
\hline
\end{tabular}

IFIS intraoperative floppy iris syndrome, $A C$ anterior capsule, $P C$ posterior capsule, $C M E$ cystoids macular oedema

report by Oshika et al. not only lacks any data on postoperative morbidity rates but does not provide any information about intraoperative strategies of performing cataract phacoemulsification in patients with IFIS [6].

Concluding: Although the use of $\alpha-1$ antagonists, especially tamsulosin, can constitute a potential risk of intraoperative complications in cataract surgery, such complications occur sporadically, and therefore, the morbidity rates should be presented in a uniform manner in order to avoid their inadvertent overestimation.

Open Access This article is distributed under the terms of the Creative Commons Attribution License which permits any use, distribution, and reproduction in any medium, provided the original author(s) and the source are credited.

\section{References}

1. Haridas A, Syrimi M, Al-Ahmar B, Hingorani M (2013) Intraoperative floppy iris syndrome (IFIS) in patients receiving tamsulosin or doxazosin-a UK-based comparison of incidence and complication rates. Graefes Arch Clin Exp Ophthalmol 251:15411545

2. Chang DF, Campbell JR (2005) Intraoperative floppy iris syndrome associated with tamsulosin. J Cataract Refract Surg 31:664-673
3. Chang DF, Braga-Mele R, Mamalis N, Masket S, Miller KM, Nichamin LD, Packard RB, Packer M (2008) ASCRS white paper: clinical review of intraoperative floppy-iris syndrome. J Cataract Refract Surg 34:2153-2162

4. Chang DF, Braga-Mele R, Mamalis N, Masket S, Miller KM, Nichamin LD, Packard RB, Packer M (2008) Clinical experience with intraoperative floppy iris syndrome. Results of the 2008 ASCRS member survey. J Cataract Refract Surg 34: 1201-1209

5. Cheung CM, Awan MA, Sandramouli S (2006) Prevalence and clinical findings of tamsulosin-associated intraoperative floppy iris syndrome. J Cataract Refract Surg 32:1336-1339

6. Oshika T, Ohashi Y, Inamura M, Ohki K, Okamoto S, Koyama T, Sakabe I, TakahashiK FY, Miyoshi T, Yasuma T (2007) Incidence of intraoperative floppy iris syndrome in patients on either systemic or topical $\alpha 1$-adrenoceptor antagonist. Am J Ophthalmol 143:150-151

7. Blouin MC, Blouin J, Perreault S, Lapoint A, Dragomir A (2007) Intraoperative floppy iris syndrome associated with a1adrenoreceptors; comparison of tamsulosin and alfuzosin. $\mathrm{J}$ Cataract Refract Surg 33:1227-1234

8. Takmaz T, Can I (2007) Clinical features, complications, and incidence of intraoperative floppy iris syndrome in patients taking tamsulosin. Eur J Ophthalmol 17:909-913

9. Nguyen DQ, Sebastian RT, Kyle G (2007) Surgeon's experiences of the intraoperative floppy iris syndrome in the United Kingdom. Eye 21:443-444

10. Altan-Yaycioglu R, Gedik S, Pelit A, Akova YA, Akman A (2009) Clinical factors associated with floppy iris signs: a prospective study from two centers. Ophthalmic Surg Lasers Imaging 40:232-238 